\title{
Peranan Wanita dalam Islam dan Feminisme Barat
}

\begin{abstract}
Hamidah Hanim
Universitas Sains Cut Nyak Dhien

hamidahhanim1512@gmail.com

Abstract

The purpose of this study is to determine the role and rights of women in Islamic and Western views. Islam is a grace to all nature and although we know that women are created from male ribs, Islam never states that women's degrees are below men. The methodology used literature studies. As for the research results that the role of women is said to be important because of the many heavy loads it has to deal with, even the burdens that men should have been imposing. Women have equal and equal rights in Islam in contrast to those prosecuted by Western women who demand equality and identification between men and women in every respect. The point of departure they use in this is that their rights must be equal, identical and comparable. There is no privilege and primacy for either of them. Equations are different from those of the identities. The gender equations many westerners had buzzed, evidently having permeated into the body of these Muslims' Muslims. They had been fooled by the thoughts of the westerners, not even a few of whom were to screech the thought. Natural law is fixed in nature to have regulated gender relations in society. So, when in society there is and there is a female subordination phenomenon, it is due to female biological factors. Some answers about the low role of public dissector women due to biological constraints, such as menstruation, pregnancy, childbirth, and breastfeeding. All of them became women's inhibitors to play a significant role in society.
\end{abstract}

Keywords: Feminism, Gender, Sharia, Islamic

\begin{abstract}
Abstrak
Adapun tujuan dalam penelitian ini adalah untuk mengetahui peran dan hak wanita dalam pandangan Islam dan Barat. Islam adalah rahmat bagi seluruh alam dan meski kita mengetahui bahwa wanita diciptakan dari tulang rusuk laki-laki, namun Islam tidak pernah menyatakan bahwa derajat wanita dibawah laki-laki. Metodologi yang digunakan studi literature. Adapun hasil penelitian bahwa Peran wanita dikatakan penting karena banyak beban-beban berat yang harus dihadapinya, bahkan beban-beban yang semestinya dipikul oleh pria. Wanita mempunyai hak yang sama dan setara dalam Islam berbeda dengan yang dituntut oleh wanitawanita Barat yang menuntut persamaan dan keidentikan antara pria dan wanita dalam segala hal. Titik tolak yang digunakan mereka dalam hal ini ialah hak-hak mereka harus sama, identik dan sebanding. Tidak ada hak pengistimewaan dan pengutamaan bagi salah satu dari keduanya. Persamaan berbeda dengan keidentikan. Persamaan gender yang banyak didengungkan oleh kaum barat, ternyata telah merasuk ke tubuh kaum muslimah umat ini. Mereka telah tertipu dengan pemikiran kaum barat, bahkan tidak sedikit yang mengekor pemikiran tersebut. Hukum alam bersifat tetap telah mengatur relasi gender di masyarakat. Jadi, apabila di dalam masyarakat terdapat dan terjadi fenomena subordinasi perempuan, hal tersebut disebabkan karena faktor biologis perempuan. Beberapa jawaban tentang rendahnya peran perempuan disektor publik karena kendala bilogis, seperti menstruasi, hamil, melahirkan, dan menyusui. Kesemuanya itu menjadi penghambat perempuan untuk berperan signifikan dalam masyarakat.
\end{abstract}

Kata Kunci: Feminisme, Gender, Islami, Syariat. 


\section{A. Pendahuluan}

Islam dan perempuan merupakan dua kata yang tidak terpisahkan. Kemuliaan perempuan dan pengakuan terhadap hak-hak perempuan muncul dan berkembang sejalan dengan era kejayaan Islam hingga saat sekarang ini. Al-qur'an mengkhususkan surat Annisa' sebagai pemuliaan terhadap perempuan, yang menggambarkan tentang hak dan kewajiban, kenyataan sosial dalam berumah tangga, bermasyarakat, dan bernegara. Di sini perempuan memainkan perannya. Peran wanita begitu penting dalam kehidupan sosial, dikarenakan ada banyak beban berat yang harus dihadapinya, bahkan beban yang semestinya dipikul oleh pria namun diambil alih oleh wanita. Oleh karena itu, secara khusus pula, Islam memuliakan perempuan tiga kali dibandingkan laki-laki. Hal ini dapat dibuktikan dengan kewajiban kita untuk berbakti kepada ibu, juga bersikap santun kepadanya. Jadi diharapkan dengan baiknya tatanan maka dapat berdampak baik pula terhadap tatanan sosial masyarakat.

Pada setiap pelaksanaan perubahan sosial, partisipasi masyarakat menjadi bagian penting untuk mendukung kesuksesan suatu perencanaan, khususnya pada pemberlakuan Syari'at Islam. Oleh sebab itu, maka pemahaman dan pelaksanaan Syari'at Islam yang dinilai melemahkan posisi perempuan dalam era global harus diluruskan kembali. Penyebaran pesan damai kepada masyarakat harus dilakukan dengan sebaik-baiknya, agar masyarakat lebih mengerti tentang bagaimana Islam mempunyai falsafah khusus mengenai hubungan hak-hak pria dan wanita dalam keluarga.

Dalam pandangan feminisme ala Barat, mereka menuntut persamaan hak antara pria dan wanita dalam segala hal. Titik tolak yang digunakan mereka dalam hal ini ialah hak-hak mereka harus sama, identik dan sebanding. Tidak ada hak pengistimewaan dan pengutamaan bagi salah satu dari keduanya. Mereka mengartikan persamaan sebagai kesederajatan dan kesebandingan. Sementara identik berarti keduanya harus persis sama. Sejarah bersaksi bahwa faktor kehancuran budaya Yunani yang paling menonjol adalah karena keluarnya para wanita secara bebas diberbagai lapangan pekerjaan. Jalanan dipenuhi oleh para wanita yang keluar rumah 
berdesak-desakan dan berkompetisi dengan kaum lelaki. Dari sini kemudian timbul fitnah. Kaum lelaki lantas kehilangan kendali atas akhlaknya. Padahal jika akhlak sebuah masyarakat lenyap maka lenyap pula eksistensi masyarakat itu. Kehancuran merajalela karena akhlak tak lagi menjadi pengendali jiwa. Tak ada lagi kebaikan di tengah manusia. Dari sini kembalilah masyarakat tersebut kepada bentuk masyarakat hewani. Masyarakat yg melampiaskan semua nafsu dan keinginan tanpa memperhatikan norma dan nilai-nilai yg ada.

Masyarakat muslim saat ini telah berada di bibir jurang kenyataan yang menyakitkan tersebut. Penyeru-penyeru pembebasan wanita gembira melihat fenomena umum di tengah masyarakat muslim. Wanita bekerja di luar rumah, pakaian yang tidak menutup aurat, hancurnya akhlak serta nilai-nilai Islam. Dan memang itulah tujuan yang mereka canangkan. Dengan kenyataaan tersebut, serta-merta masyarakat muslim menjadi masyarakat yg terhina, terbelakang dan ketinggalan dalam segala bidang kehidupan.

Kelompok masyarakat yang mudah terpengaruh dengan isu feminisme ala Barat salah satunya adalah mahasiswi. Sebab mereka termasuk kelompok rentan pelanggar qanun (Perda) dalam lingkungan pelaksanaan Syari'at Islam yang saat ini sedang dalam evaluasi karena masih belum mampu menjawab permasalahan umat secara keseluruhan. Perkembangan fisik dan psikis yang dialami mahasiswa dalam kurun waktu usia 19 tahun hingga usia 23 tahun (usia remaja), dihadapkan pada pertanyaan tentang "siapakah saya?" dan “kemakah saya akan pergi?" (Atkinson, Atkinson, dan Hilgard, 2011:139). Lebih lanjut mereka menunjukkan adanya perubahan sangat besar dalam sikap terhadap kegiatan seksual. Pandangan mengenai hubungan seks sebelum kawin, homoseksualitas, hubungan seks di luar pernikahan, serta perilaku seks tertentu lebih terbuka dan bebas dibandingkan dengan masa lalu. Melahirkan kompleksitas permasalahan pada generasi muda (baca: mahasiswa) dengan aspek pertumbuhan dan perkembangan fisik dan psikhis.

Proses mencari identitas jika dihubungkan dengan penerapan Syari'at Islam seharusnya menjadi searah karena tujuan penerapan qanun memberikan kepastian hukum tentang bagaimana seharusnya tindakan 
dilakukan dan tidak melaggar hukum. Hanya saja, ketidaksiapan menjadi faktor penghambat dalam capaian maksimal pelaksanaan Syari'at Islam di kalangan mahasiswa. Hingga dalam masa 20 tahun terakhir.

Ketidaksiapan mahasiswa, kelompok pendukung (ulama: Kiyai, Ustadz, dan Ustadzah) dan aparat pemerintah (Polisi Syari'at) terhadap hukum Syari'at, pada gilirannya menimbulkan campur tangan (intervensi) dari luar dengan perkembangan wacana tentang: 1) kenapa hukum Syari'at Islam harus diterapkan?; 2) kenapa diskriminasi hanya kaum perempuan?; 3) kenapa masih diberlakukan hukum tidak adil, malah juga kerap dilontarkan dikalangan masyarakat. Hal tersebut rentan merasuki pikiran mahasiswi yang masih belum matang secara kejiwaan. Seakan perempuan merupakan sumber permasalahan yang menyebabkan disharmonisasi kehidupan sosial. Sebagian kecil orang masih mempermasalahkan formalisasi syariat Islam dengan alasan melanggaran hak asasi manusia (HAM), kebebasan berekspresi, dan anggapan hanya perempuan menjadi objek sweeping Polisi Syariat (WH) di jalan raya karena tidak memakai jilbab, memakai celana sempit atau baju kurang sopan.

Perempuan, tubuh, alam, tidak terpisahkan. Hukum-hukum alam bersifat tetap telah mengatur relasi gender di masyarakat (Haryanto, 2012: 106). Jadi, apabila di dalam masyarakat muncul fenomena subordinasi perempuan, hal tersebut disebabkan karena faktor biologis perempuan. Beberapa jawaban tentang rendahnya peran perempuan disektor publik karena kendala-kendala bilogis, seperti menstruasi, hamil, melahirkan, dan menyusui. Kesemuanya itu menjadi penghambat perempuan untuk berperan signifikan dalam masyarakat.

Qanun Syari'at Islam paling popular masih berkutat soal judi, minuman keras dan khalwat. Kenapa dalam masalah riil yang dihadapi masyarakat, seperti korupsi, belum terjangkau oleh ketentuan Syari'at. Intervensi pemikiran dari luar tentang ketidakmampuan Syari'at Islam menjadi solusi kehidupan sosial, terutama bagi perempuan, menimbulkan kesan beratnya syariat Islam yang diwajibkan kepada perempuan. Sehingga dalam artikel ini, penulis akan mengupas mengenai peran perempuan dalam sudut pandang Islam. 


\section{B. Metode Penelitian}

Penelitian ini merupakan eksploratif menggunakan studi literatur, yakni telaah atas buku-buku dan sumber media baru (internet) sebagai rujukan tentang definisi gender, isu gender, dan pendekatan sosial dan budaya.

\section{Hasil Dan Pembahasan}

\section{Emansipasi Perempuan Menurut Pandangan Islam dan Barat}

Emansipasi berarti persamaan hak dalam hukum (kaum wanita sama haknya dengan kaum pria) (Poerwadarminta, 1982: 270). Pengakuan atas kedudukan perempuan yang mulia dalam Islam dibuktikan dengan penghapusan tradisi-tradisi yang bersifat diskriminatif terhadap mereka. Islam juga telah mengatur peran dan tugas perempuan. Dalam keluarga, seorang perempuan memiliki peran sebagai ibu rumah tangga yang bertugas merawat anak dan melayani suami. Selain peran di atas, Islam juga menjamin hak-hak perempuan.

Hak-hak itu antara lain adalah 1) hak untuk mendapatkan warisan (seorang anak perempuan mendapat setengah anak laki-laki); 2) hak mendapat pendidikan; 3) dan hak memilih pasangan. Islam datang dengan tugas-tugas syariat yang dibebankan kepada pria dan wanita, dengan hukumhukum yang menangani berbagai tindakan dan tugas masing-masing. Islam tidak memandang persamaan hak (emansipasi) atau keutamaan antara wanita dan pria, tetapi Islam memandang sebagai suatu problema yang perlu diatasi (Al-Baghdadi, 1997: 17). Masalah emansipasi tidak ada dalam hukum Islam, yang ada hanya hukum syariat mengenai peritiwa yang terjadi atas insan baik pria maupun wanita.

Berbeda dengan Islam yang menyandarkan ajarannya pada wahyu Ilahi, Barat modern menerapkan sistem sekuler-liberal yang menolak agama masuk dalam wilayah publik. Penerapan sekuler-liberal di peradaban Barat dimulai sejak runtuhnya hegemoni kekuasaan gereja pada abad ke17. Saat ini, peradaban Barat menjadi penguasa dunia. Mereka mendominasi seluruh 
bidang kehidupan. Hal ini yang membuat mereka menjadi peradaban pilihan manusia. Ajaran mereka menjadi acuan yang diikuti oleh negara-negara lain. Salah satunya adalah feminisme.

Feminisme adalah gerakan kaum perempuan yang memperjuangkan hak-hak asasi mereka. Gerakan ini muncul pertama kali antara tahun 1880 sampai dengan 1920. Kemunculan gerakan ini dipengaruhi oleh pemikiran Mary Wollstonecraft lewat bukunya yang berjudul "Vindication of the Rights of women". Buku ini dipublikasikan di Inggris pada tahun 1792. Dalam perkembangannya, gerakan feminisme melahirkan sebuah gerakan baru yang bernama gender. Gerakan ini mengkritisi ketidaksamaan antara laki-laki dan perempuan dalam ekonomi dan posisi jabatan. Teori feminisme menganalisis berbagai isu-isu gender, khususnya yang berkaitan dengan bentuk-bentuk penindasan lain, seperti penindasan yang berbasis pada kelas, ras ata etnisitas, seksualitas, umur, kemampuan, dan sebagainya (Haryanto, 2012: 110).

Feminisme multikulutural meyakini bahwa perempuan tidak akan eksis apabila hanya berperan sebagai "perempuan" di masyarakat. Pengalamannya dibentuk oleh karakteristik penting lain dan perempuan mungkin mengalami penindasan di berbagai level, seperti rasisme, klasisme, dan heteroseksisme (Haryanto, 2012: 110). Feminis aliran ini menekankan pentingnya perubahan sistem apabila menghendaki masyarakat yang benarbenar adil. Teori feminis memiliki tiga ciri, yakni: (1) memfokuskan (meski tidak ekslusif) pada persoalan ketimpangan, hambatan, dan kontradiksikontradiksi yang ada dalam relasi gender; (2) sebuah asumsi bahwa hubungan gender tidak imun, tetapi lebih mudah merubah kreasi sosial; (3) mempunyai komitmen normatif bahwa masyarakat harus mengembangkan aturan gender yang lebih setara.

\section{2) Tinjauan Peranan Wanita dalam Islam}

Peran adalah pelaksanaan hak-hak dan kewajiban sesuai dengan kedudukan seseorang. Peran wanita adalah serangkaian perilaku yang diharapkan sesuai dengan posisi social yang diberikan kepada wanita. Peran menerangkan pada apa yang harus dilakukan wanita dalam suatu situasi 
tertentu agar dapat memenuhi harapan mereka sendiri dn harapan orang lain.

Di dalam kehidupan wanita selalu memiliki peran antara lain :

a. Sebagai Istri

Keberhasilan seorang suami sangat didukung oleh istri. Demikian eratnya hubungan antara suami dan istri sehingga Allah menyebutkan bahwa perempuan adalah pakaian bagi suaminya. Untuk itu peran wanita sebagai istri di antaranya :1)memposisikan diri sebagai istri sekaligus ibu, teman, dan kekasih bagi suami; 2) menjadi teman diskusi seraya memberikan dukungan motivasi kepada suami; 3) berbagi rasa suka dan duka serta memahami keadaan keadaan, kedudukan, tugas dan tanggung jawab suami; 4)Menjaga kesesuaian hubungan suami istri.

b. Sebagai Ibu

Wanita selaku orang tua merupakan cermin bagi anak-anak di dalam keluarga. Anak-anak cenderung meniru apa yang ia lihat dan temukan dalam keluarga. Sebab anak diibaratkan bagaikan radar yang akan menangkap segala macam bentuk sikap dan tingkah laku yang terdapat dalam keluarga. Jika yang ditangkap adalah hal-hal buruk, maka ia akan menjadi buruk meskipun pada hakikatnya anak dilahirkan dalam keadaan suci. Seorang ibu memegang peran penting dalam mendidik anak, walaupun ayah juga tetap ikut bertanggung jawab, tetapi peran ibu jauh lebih penting sebab dialah yang menjadi pendidik utama dalam lingkungan keluarga. Rumah tangga merupakan sekolah pertama tempat mereka belajar hidup dan kehidupan, belajar mengenal yang benar dan yang salah, belajar menghormati yang tua dan sanak keluarga. Wanita yang menjadi salah-satu unsur dalam keluarga merupakan penentu arah sikap dan perilaku anak pada masa mendatang. Muhammad Taqi Falsafi menyatakan bahwa lingkungan keluarga merupakan sekolah yang mampu mengembangkan potensi tersembunyi dalam jiwa anak dan mengajarkan kepadanya tentang kemuliaan dan kepribadian, keberanian dan kebijaksanaan, toleransi dan kedermawanan, serta sifat-sifat mulia lainnya. 


\section{c. Sebagai Anggota Masyarakat}

Posisi dan kedudukan perempuan dalam kehidupan bermasyarakat dan bernegara sudah sangat jelas, yakni sebagai anggota masyarakat dan sebagai warga negara yakni memiliki sejumlah hak dan kewajiban. Tidak ada perbedaan antara laki-laki dan perempuan. Perintah Allah untuk berbuat adil dalam seluruh bidang kehidupan, baik ranah domestik maupun publik sangat tegas dan tandas, keadilan mesti ditegakkan. Keadilan merupakan prinsip ajaran Islam yang mesti ditegakkan dalam menata kehidupan manusia, prinsip itu harus selalu ada dalam setiap norma, tata nilai dan prilaku umat manusia dimanapun dan kapanpun. Menurut pandangan Islam wanita dan pria adalah sama, karena mereka merupakan kelompok umat manusia yang satu. Atas dasar itu maka Islam memberikan tanggung jawab syariah serta dipersamakan hak-hak dan kewajiban atas mereka. Hak-hak dan kewajiban antara wanita dan pria dalam ajaran Islam, meliputi: 1) persamaan di dalam memikul tanggung jawab, 2) wanita dan pria memiliki hak-hak yang sama serta menanggung kewajiban yang sama (Baghdadi, 1997: 21). Islam tidak membedakan antara wanita dan pria di dalam mengajak manusia kepada keimanan. Islam juga telah mempersamakan berbagai kewajiban yang berkenaan dengan ibadah, seperti: shalat, puasa, zakat dan haji dari segi kewajiban pelaksanaannya. Allah SWT tidak membedakan antara wanita dan pria dalam hak dan kewajiban penyembahan kepadaNya. Islam mempersamakan antara wanita dan pria dalam tata hukum muamalat, seperti jual beli (al-bai'), perwakilan (wahala), tanggungan atau jaminan (kafalah), dan aqad-aqad lainnya yang berkaitan dengan sesama manusia.

\section{3) Perubahan Sosial Masyarakat dalam Pandangan Islam}

Perubahan sosial itu mencakup seluruh aspek kehidupan sosial yang terus menerus berubah. Perubahan sosial menunjukan kepada perubahan fenomena sosial diberbagai tingkat kehidupan manusia, mulai dari tingkat individual hingga tingkat dunia. Lauer (2001) mendefenisikan perubahan sosial sebagai perubahan penting dari struktur sosial, yaitu pola-pola perilaku 
dan struktur sosial, termasuk ekspresi mengenai struktur seperti norma, nilai dan fenomena kultural.

Perubahan-perubahan yang terjadi di masyarakat timbul dalam beberapa bentuk. Ada perubahan yang terjadi secara lambat (evolusi) dan ada perubahan secara cepat (revolusi). Perubahan lambat terjadi dengan sendirinya sebagai adaptasi masyarakat dengan kondisi lingkungannya. Perubahan cepat pada umumnya terjadi secara sengaja, tetapi melalui perencanaan dan pengorganisasian para pengusungnya yang kemudian dapat merubah sendi-sendi pokok kehidupan masyarakat dan lingkungan (Soekanto, 1997: 345)

Bentuk lain dari perubahan yang terjadi di dalam masyarakat bisa menjadi perubahan yang direncanakan dan perubahan yang tidak direncanakan. Perubahan yang direncanakan adalah perubahan yang telah disiapkan oleh pihak-pihak yang menghendaki adanya perubahan (agent of change) (Djamil, 2013: 10). Upaya tersebut biasa disebut dengan rekayasa sosial (social engineering) atau perencanaan sosial (social planning). Sementara itu, perubahan yang tidak direncanakan merupakan perubahan yang terjadi tanpa dikehendaki, berlangsung di luar jangkauan pengawasan masyarakat, sehingga segala akibat yang muncul dari perubahan itu bukan dikehendaki oleh masyarakat (Soekanto, 1997: 345). Lebih lanjut Djamil (2013:11) menyatakan bahwa fungsi hukum apabila dihadapkan pada perubahan sosial dan ekonomi akan menempati salah satu dari dua fungsi hukum, yakni sebagai sarana kontrol sosial (social control) dan sebagai sarana untuk mengubah sosial masyarakat (social engineering).

Hukum Islam merupakan alat untuk mengubah masyarakat, menciptakan suatu tatanan baru dalam masyarakat, dan merupakan alat kontrol sosial yang mengatur hubungan manusia dengan Allah SWT, sesama manusia, dan dengan alam sekitarnya. Sebagai kontrol dalam sistem kehidupan masyarakat muslim, hukum Islam bertujuan untuk mencapai keadilan mutlak, yang diwujudkan dengan perbaikan dan kemampuan pemenuhan rasa keadilan manusia di dunia (kehidupan saat ini) dan akhirat 
(kehidupan setelah di dunia). Hingga mampu menjadi solusi untuk menjawab segala tantangan yang muncul di masyarakat.

Hukum Islam juga digunakan dalam dinamika ijtihad (Djamil, 2013: 13). Ulama biasanya menjawab tantangan baru dengan menggali hukum dari sumber-sumbernya melalui ijtihad. Secara umum ijtihad dapat dikatakan sebagai upaya berpikir secara optimal dan sungguh-sungguh dalam menggali hukum Islam dari sumbernya, untuk memperoleh jawaban terhadap permasalahan hukum yang timbul dalam masyarakat (Zahrah, 1958; Al-halabi, 1996). Ijtihad baik secara langsung maupun tidak langsung, tidak dapat dilepaskan dari perubahan-perubahan sosial, sedangkan perubahanperubahan sosial harus mendapat kontrol dan diberi arah oleh hukum sehingga dapat memenuhi hajat dan kemaslahatan umat (Rusli dalam Djamil, 2013: 14). Perubahan dapat terlaksana melalui pemahaman dan penghayatan nilai-nilai Al-Quran, serta kemampuan memanfaatkan dan menyesuaikan diri dengan hukum-hukum sejarah.

Ruang lingkup hukum Islam berbeda dengan hukum-hukum yang bersumber dari pemikiran manusia. Hukum-hukum dari hasil pemikiran manusia hanya terbatas pada hubungan manusia dengan manusia lain dan hubungan manusia dengan benda dan secara pasti dapat diubah bila hukum tersebut tidak lagi dapat memenuhi kebutuhan hidup manusia (Moslehuddin, 1991: 47). Ruang lingkup hukum Islam memenuhi ketidakmampuan hukumhukum hasil pemikiran manusia yang memunculkan pengaturan hubungan manusia dengan Tuhan. Hubungan manusia dengan Tuhannya diatur dalam bentuk hukum-hukum tentang ibadah dan hubungan manusia dengan sesamanya dan alam sekitarnya diatur dalam tata hukum mu'amalah

\section{4) Gender (Emansipasi dalam Islam)}

Islam tidak membedakan antara laki-laki dan perempuan kecuali pada apa yang dilakukan sebagai bentuk ketaatannya. Kedatangan Islam sebagai akidah, akhlak, dan hukum, tidak memandang persamaan hak (emansipasi) sebagai keutamaan antara wanita dan pria. Islam memandang wanita dan pria sebagai suatu problema yang perlu diatasi (Al-Baghdadi, 1997: 17). Masalah 
emansipasi atau bukan emansipasi antara wanita dan pria bukan merupakan topik tidak dibahas dalam Islam, dan yang ada hanya hukum syariat mengenai peristiwa yang terjadi atas insan baik pria maupun wanita. Emansipasi wanita terhadap pria bukan merupakan suatu permasalahan yang patut didiskusikan atau menjadi sasaran yang perlu diperhitungkan dalam Islam.

Jadi masalah ini tidak akan berpengaruh terhadap kehidupan sosial. Islam tidak terkait dengan istilah emansipasi, karena penegakan aturan kehidupan wanita dan pria berdasarkan kenyataan yang menjamin keterpaduan serta kemajuan golongan dan masyarakat selain memberikan kebahagiaan yang hakiki kepada wanita dan pria sesuai dengan kemuliaan martabat manusia yang dianugerahkan oleh Allah SWT. Hak dan kewajiban wanita dan pria dalam Islam merupakan kepentingan masing-masing mereka sesuai dengan kehendak-Nya. Penolakan dan penerimaan menunjukkan tabiat manusiawi menghendakinya.

\section{5) Emansipasi dalam Feminisme}

Beberapa teori feminisme terpengaruh dari pemikiran-pemikiran para founding fathers sosiologi yang mengasumsikan bahwa perempuan dan lakilaki secara alamiah berbeda baik dalam hal intelektualitas, emosi, dan moralitasnya. Herbert Spencer (sosiolog Inggris, feminis liberal pertama) dalam karyanya social statistic yang secara khusus dalam bab "Hak-hak Perempuan." Ia berpendapat bahwa perempuan dan laki-laki berhak mendapatkan hak yang sama. Hal itu disebabkan oleh hanya ada perbedaan mental sepele di antara keduanya. Selama empat tahun Spencer mengembangkan Darwinisme sosial dan sampai pada kesimpulan bahwa biologi (bukan budaya) yang menghasilkan perbedaan seks yang amat besar. Perempuan memiliki otak yang lebih kecil, kurang memiliki kepekaan dalam keadilan dan kemampuan rasionalisasi yang dibutuhkan di dalam kehidupan dibalik pengurusannya terhadap suami dan anak-anak. Lebih dari itu, perempuan secara alamiah cenderung memilih untuk dilindungi oleh laki-laki yang kuat. Perempuan yang diizinkan memasuki dunia publik akan membahayakan kemajuan peradaban (Chafetz, 2006). 
Senada dengan itu, Auguste Comte (Haryanto, 2013: 106), juga berpendapat bahwa karena memiliki superioritas dalam hal emosional dan spiritual, perempuan cocok tinggal di rumah dan mengurus keluarga. Selain itu, inferioritas intelektual yang dibandingkan laki-laki menyebabkan perempuan tidak cocok menjadi apapun selain sebagai ibu rumah tangga. Kesimpulan yang sama juga dikemukakan oleh Sosiolog Jerman, Ferdinand Tonnies dan sosiolog Italia Vilfredo Pareto. Emile Durkheim (Prancis), juga menggunakan pendakatan biologis dalam menjelaskan subordinasi perempuan.

Durkheim dalam bukunya berjudul Suicide, membuktikan bahwa perkawinan mengakibatkan efek yang berbeda bagi laki-laki. Misalnya, tingkat bunuh diri pada laki-laki menikah lebih rendah dibandingkan dengan tingkat bunuh diri perempuan menikah. Ia menyimpulkan bahwa perkawinan pada suatu saat harus direformasi. Akan tetapi, dalam waktu dekat, laki-laki harus diproteksi dari bunuh diri melalui pemeliharaan dari bentuk-bentuk perkawinan yang menghasilkan lebih banyak stress dan kerugian bagi perempuan. Pembenarannya ini berasal dari data yang menunjukkan bahwa peningkatan bunuh diri pada wanita kawin lebih rendah dibandingkan dengan laki-laki yang tidak kawin karena perempuan mempunyai lebih sedikit kebutuhan sosiabilitas dan lebih instingtif. Kehidupa mental wanita yang kurang berkembang dan karena itu lebih mudah puas sementara laki-laki kehidupan mentalnya lebih kompleks dan keseimbangan psikologisnya lebih sulit dicapai dan kebutuhan akan perlindungan dilakukan melalui pengaturan perkawinan.

Ide-ide dalam teori feminisme berusaha mendefinisikan perempuan dalam kebudayaan dan masyarakat, termasuk menjawab berbagai pertanyaan besar mengenai gambaran perempuan. Teori feminisme diakui sebagai salah satu teori sosial yang sulit dideskripsikan, digambarkan secara jelas berdasarkan fakta sosial yang ada, apalagi digeneralisasikan, yakni penyamaan secara umum terhadap fakta sosial tentang perempuan dalam sebuah sistem sosial. 
Tuchman (2008: 988), mengidentifikasi setidaknya ada tiga hal yang membuat teori feminism sulit dideskripsikan dan digeneralisir, berdasarkan: (1) Teori feminisme bersifat interdisipliner, kritikus sastra, sejarawan seni, musikolog, dan filsuf merupakan beberapa spesialis yang berhubungan dengan humaniora Kesemuanya menawarkan berbagai ide dan penjelasan yang saling bertentangan yang saling bertentangan mengenai posisi perempuan dalam kebudayaan dan masyarakat. Demikian pula para sosiolog, antropolog, ekonom, psikolog, dan ahli psikoanalisis. Para ahli keilmuan yang interdisipliner tersebut tidak ada yang menjelaskan mengenai ruang lingkup teori feminsime kontemporer; (2) Teori feminisme berbasis pada gerakan sosial yang sangat dipengaruhi oleh konsen politik yang bersifat lokalitas dan temporer. Di Eropa, gerakan feminisme menentang institusional seksisme dan rasisme serta ketimpangan pendapatan dan kesejahteraan. Sementara itu perempuan di negara-negara berkembang menyuarakan mengenai pentingnya penerapan teori feminisme yang berbasis pengalaman masingmasing negara; (3) Teori feminisme tidak hanya eksis dalam konteks sosiopolitik, tetapi mendapatkan data dan informasi justru pada konteks tersebut. Dengan demikian, teori-teori feminisme mengonfrontasikan isu-isu epistemologis, seperti makna objektivitas dan cara bagaimana laki-laki mendominasi di berbagai budaya. Berbeda dengan para teori sosial lain, para feminis mengusung dua isu, yakni: (a) hubungan yang tidak terpisahkan antara ide-ide dengan metode penelitiannya, serta (b) bagaimana ide-ide dan metode dominan dipengaruhi oleh hegemoni laki-laki dalam diskursus ilmiah dan akademik.

\section{Kesimpulan}

Islam tidak mengenal istilah emansipasi wanita, sebab Islam telah memberikan tempat khusus untuk memuliakan mahkluk luar biasa yang bernama wanita. Islam menempatkan kedudukan yang sama antara laki-laki dan wanita sehingga keimananlah yang mampu membedakan derajat keduanya. Dan hal inilah yang membedakannya dengan pandangan Barat yang terus-menerus menyuarakan isu feminisme. Tuntutan atas persamaan hak 
antara laki-laki dan wanita menjadi problem tersendiri yang pada akhirnya menjadi permasalahan baru yang mereka hadapi.

\section{DAFTAR PUSTAKA}

Adil Fathi Abdullah. 2001. Menjadi Ibu Ideal. Jakarta: Pustaka Al-Kautsar.

Al-Baghdadi, Abdurrahman. 1997. Emansipasi, adakah dalam Islam: Suatu tinjauan syariat Islam tentang kehidupan wanita. Jakarta: Gema Insani Press.

Djamil, Fathurrahman. 2013. Hukum ekonomi Islam: Sejarah, teori, dan konsep. Jakarta: Sinar Grafika.

Giddens, Anthony., Pen. Maufur dan Daryanto. 2010. Teori strukturasi: Dasardasar pembentukan struktur sosial masyarakat. Yogyakarta: Pustaka pelajar.

Haryanto, Sindung. 2013. Spektrum teori sosial: Dari klasik hingga postmodern. Jogjakarta: Ar-Ruzz Media.

Jane Pilcher dan Imelda Whelehan. 2004. Fifty key concepts in gender studies. London: Sage Publication.

Lauer, Robert H. 2001. Perspektif tentang perubahan sosial. Jakarta: Rineka Cipta.

Majid, Abdul. 2007. Syari'at Islam dalam realitas sosial: Jawaban Islam terhadap masyarakat di wilayah syari'at. Banda Aceh: Yayasan Pena \& Ar-Raniry Press.

Muhammad Taqi Falsafi. 2002. Anak antara kekuatan gen dan pendidikan. Bogor: Cahaya.

Musda Mulia. 2007. Islam dan inspirasi kesetaraan gender. Yokyakarta: Kibar Press.

Muchtar, Yati. 2001. Gerakan perempuan Indonesia dan politik gender orde baru. Jurnal Perempuan Untuk Pencerahan Dan Kesetaraan, No. 14.

Salam, Tgk., dan Anwar Fuadi, A. 2003. Dapatkah syariat Islam diberlakukan di Aceh? Banda Aceh: Amal Sejahtera. 